\title{
Pseudomonas simiae sp. nov., isolated from clinical specimens from monkeys (Callithrix geoffroyi)
}

\author{
Ana I. Vela, ${ }^{1}$ María C. Gutiérrez, ${ }^{2}$ Enevold Falsen, ${ }^{3}$ Eduardo Rollán, ${ }^{4}$ \\ Isabel Simarro, ${ }^{1}$ Pilar García, ${ }^{4}$ Lucas Domínguez, ${ }^{1}$ Antonio Ventosa ${ }^{2}$ \\ and José F. Fernández-Garayzábal ${ }^{1}$ \\ 'Departamento Sanidad Animal, Facultad de Veterinaria, Universidad Complutense, Avda Puerta \\ de Hierro s/n, 28040 Madrid, Spain \\ ${ }^{2}$ Departamento de Microbiología y Parasitología, Facultad de Farmacia, Sevilla, Spain \\ ${ }^{3}$ Culture Collection, Department of Clinical Bacteriology, University of Göteborg, Sweden \\ ${ }^{4}$ Departamento de Medicina y Cirugía Animal, Facultad de Veterinaria, Universidad \\ Complutense, Madrid, Spain
}

Correspondence José F. Fernández-Garayzábal garayzab@vet.ucm.es
Pseudomonads are widely distributed in agricultural soils, in freshwater and marine environments and in plants and animals. The genus Pseudomonas includes species that can be pathogenic for humans and animals (Palleroni, 1984, 1993). Pseudomonas aeruginosa is currently the most significant pathogenic species in the genus Pseudomonas. This micro-organism has been frequently associated with different human and animal infections (Lausen et al., 1986; Coalson et al., 1988; Las Heras et al., 1999; Daly et al., 1999; Poirel et al., 2004). Other Pseudomonas species have also been involved in human infections, such as Pseudomonas stutzeri (Jiraskova \& Rozsival, 1998; Puzenat et al., 2004), Pseudomonas fluorescens (Smith et al., 2002) and Pseudomonas putida (Franzetti et al., 1992; Lombardi et al., 2002). However, animal infections caused by Pseudomonas species other than P. aeruginosa are often not reported. In this work, we have used phenotypic and molecular genetic methodologies to facilitate the characterization of some Pseudomonaslike organisms recovered from clinical samples from

The GenBank/EMBL/DDBJ accession number for the 16S rRNA gene sequence of strain CCUG $50988^{\top}$ is AJ936933. monkeys (Callithrix geoffroyi). On the basis of our findings, we propose a novel Pseudomonas species that is taxonomically affiliated to the ' $P$. fluorescens intrageneric cluster' described by Anzai et al. (2000).

A juvenile female monkey (C. geoffroyi) and its offspring were submitted to the necropsy service of the Veterinary School Hospital in Madrid, Spain. These animals were housed in the same cage at the submitting facility, a Primate Conservation Centre, and were separated from the rest of the animals. The female monkey was found dead 2 days prior to the death of its offspring. Neither of these two animals had shown clinical signs of disease during the $24 \mathrm{~h}$ preceding their deaths. Glomerulonephritis with secondary uraemic pneumonitis and acute bronchointerstitial pneumonia were the clinical signs observed after post-mortem examination of the female monkey and the offspring, respectively. Gram-stained sections of the lungs of the offspring revealed the presence of Gram-negative rods inside the pulmonary alveoli.

Samples from the lungs, liver and brain of the female monkey and its offspring were taken for microbiological 
analysis (under aseptic conditions to avoid environmental contamination) and kept under refrigeration until they were processed in the laboratory. Tissue samples were surfaceplated on Columbia blood agar and MacConkey agar (bioMérieux) and incubated aerobically and under anaerobic conditions for $48 \mathrm{~h}$ at $37^{\circ} \mathrm{C}$. A rod-shaped organism was isolated in pure culture from the lungs, liver and brain of the offspring (isolates $\mathrm{OLu}, \mathrm{OB}$ and $\mathrm{OLi}^{\mathrm{T}}$ ) and from the liver and brain of the female monkey (isolates MLi and MB). Oxidase activity was tested with oxidase test sticks (Oxoid). The isolates were cultured on tryptic soy agar (bioMérieux). Motility was observed by means of the hanging drop method and in semi-solid media. The temperature range for growth was determined after cultivation of the isolates in tryptic soy broth (bioMérieux) for $24 \mathrm{~h}$ at 30,37 and $42{ }^{\circ} \mathrm{C}$ and for 3 days at 10 and $4{ }^{\circ} \mathrm{C}$. The ability of the isolates to produce a fluorescent pigment was tested on King's B medium (King et al., 1954). Growth in $6.5 \% \mathrm{NaCl}(\mathrm{w} / \mathrm{v})$ was also examined. Biochemical identification was achieved using the commercial API $20 \mathrm{NE}$ and API ZYM systems (bioMérieux) and Biolog GN Microplates (Biolog) according to the manufacturers' instructions. The clinical isolates were molecularly characterized by PFGE according to the specifications of Blanco et al. (2002), with the XbaI (Promega) and SpeI (MBI Fermentans) restriction endonucleases.

Phylogenetic characterization was performed using $16 \mathrm{~S}$ rRNA gene sequencing, as described previously (Collins et al., 1999). A large fragment (approx. 1450 bases) of the $16 \mathrm{~S}$ rRNA gene of two isolates (MLi and $\mathrm{OLi}^{\mathrm{T}}$ ) and $1000 \mathrm{nt}$ from the other three isolates $(\mathrm{MB}, \mathrm{OB}, \mathrm{OLu})$ were amplified by using a PCR and were directly sequenced using a Taq DyeDeoxy terminator cycle sequencing kit (Applied Biosystems) and an automatic DNA sequencer (model 373A; Applied Biosystems). The closest described relatives of the novel isolates were determined by performing searches of GenBank using the FASTA program (Pearson, 1994). These closely related sequences were retrieved from GenBank and aligned with the newly determined sequences using the DNATools program (Rasmussen, 1995). Phylogenetic trees were constructed according to two different methods: a neighbour-joining algorithm (Saitou \& Nei, 1987), performed with the programs DNATools and TREEVIEW (Page, 1996), and a maximum-likelihood analysis obtained by using the PHYLIP package (version 3.57; Felsenstein, 1993). The stability of the groupings was estimated by bootstrap analysis (1000 replications). Fatty acid methyl esters were prepared and analysed as described by Kämpfer \& Kroppenstedt (1996).

The genotypic relatedness of two clinical isolates $\left(\mathrm{OLi}^{\mathrm{T}}\right.$ and $\mathrm{MLi})$ and between one isolate $\left(\mathrm{OLi}^{\mathrm{T}}\right)$ and Pseudomonas poae DSM $14936^{\mathrm{T}}$, Pseudomonas trivialis DSM $14937^{\mathrm{T}}$ and Pseudomonas extremorientalis $\mathrm{KMM} 3447^{\mathrm{T}}$ were also assessed by means of DNA-DNA hybridization. DNA was extracted and purified by the method of Marmur (1961). DNA-DNA hybridization was studied using the competition procedure of the membrane method of Johnson (1994), described in detail by Arahal et al. (2001). The hybridization experiments were carried out under optimal conditions, at a temperature of $49.5^{\circ} \mathrm{C}$, which is within the limits of validity for the filter method (De Ley \& Tijtgat, 1970). The percentage hybridization was calculated as described by Johnson (1994). Three independent determinations were carried out for each experiment and the results reported are mean values. The $\mathrm{G}+\mathrm{C}$ content of the DNA was determined from the mid-point value $\left(T_{\mathrm{m}}\right)$ of the thermal denaturation profile (Marmur \& Doty, 1962) obtained with a PerkinElmer UV-Vis Lambda 20 spectrophotometer at $260 \mathrm{~nm}$; this instrument was programmed for temperature increases of $1.0{ }^{\circ} \mathrm{C} \mathrm{min}^{-1}$ by using a Peltier temperature programmer (Perkin-Elmer). The $T_{\mathrm{m}}$ value was determined in $0 \cdot 1 \times$ SSC buffer $(0 \cdot 15 \mathrm{M} \mathrm{NaCl}$ buffered with $0 \cdot 015 \mathrm{M}$ trisodium citrate, $\mathrm{pH} 7 \cdot 0$ ) by using a graphic method described by Ferragut \& Leclerc (1976) and the G+C content was calculated from this temperature by using the equation of Owen \& Hill (1979). The $T_{\mathrm{m}}$ value of reference DNA from Escherichia coli NCTC 9001 was taken as $74 \cdot 6{ }^{\circ} \mathrm{C}$ in $0 \cdot 1 \times$ SSC (Owen \& Pitcher, 1985).

The five isolates were Gram-negative, non-spore-forming rods. The cells were catalase- and oxidase-positive, strictly aerobic and motile. They were slightly $\beta$-haemolytic. All of the isolates grew on MacConkey agar. Growth between 4 and $37^{\circ} \mathrm{C}$ was observed, but the isolates did not grow at $42{ }^{\circ} \mathrm{C}$. All five isolates were able to grow in $6.5 \% \mathrm{NaCl}$. On tryptic soy agar, a yellow pigment was observed and a fluorescent pigment was produced on King's B medium. The isolates displayed identical phenotypic profiles in the commercial API $20 \mathrm{NE}$ system. All of the isolates reduced nitrate and nitrite, hydrolysed gelatin and gave a positive reaction for arginine dihydrolase. None of the isolates produced indole, $\beta$-galactosidase or acid from glucose, and all failed to hydrolyse urea and aesculin. Caprate, L-malate and citrate were assimilated, but $N$-acetyl-D-glucosamine, maltose, adipate and phenylacetate were not. In the API ZYM system, positive reactions for esterase C4, ester lipase C8, leucine arylamidase and acid phosphatase and a weak reaction for valine arylamidase were detected. All other tests were negative. The isolates were characterized further using the Biolog identification system. The results of the Biolog GN assay are indicated in the species description. In terms of their overall cellular morphology and biochemical characteristics, the novel isolates somewhat resembled members of the family Pseudomonadaceae. To clarify the association between the novel monkey isolates and the family Pseudomonadaceae, one representative strain, $\mathrm{OLi}^{\mathrm{T}}$, was subjected to cellular fatty acid analysis. The profile of strain $\mathrm{OLi}^{\mathrm{T}}$ was characterized by the presence of $\mathrm{C}_{10: 0} 3-\mathrm{OH}$ and $\mathrm{C}_{12: 0}$ 3-OH fatty acids, which is consistent with their classification as sensu stricto pseudomonads (Oyaizu \& Komagata, 1983). The major fatty acids of the strain were $\mathrm{C}_{16: 0}, \mathrm{C}_{16: 1} \omega 7 c, \mathrm{C}_{18: 1} \omega 7 c$ and $\mathrm{C}_{17: 0}$ cyclo (mean contents $30 \cdot 3,27 \cdot 0,12 \cdot 3$ and $11 \cdot 7 \%$, respectively). The isolate also contained moderate or small amounts of saturated $\left(\mathrm{C}_{12: 0}\right.$, $\mathrm{C}_{12: 0} 2-\mathrm{OH}, \mathrm{C}_{14: 0}, \mathrm{C}_{15: 0}, \mathrm{C}_{17: 0}, \mathrm{C}_{19: 0}(\omega 8 c$ cyclo), unsaturated 
$\left(\mathrm{C}_{18: 2} \omega 6,9 c, \mathrm{C}_{16: 1} \omega 7 c\right.$ DMA) and branched (iso- $\mathrm{C}_{15: 0} 3-$ $\mathrm{OH})$ fatty acids.

Three different assays confirmed that the DNA G+C contents of isolates $\mathrm{OLi}^{\mathrm{T}}$ and $\mathrm{MLi}$ were $49 \cdot 7$ and $52.3 \mathrm{~mol} \%$, respectively; these percentages being lower than those associated with members of the genus Pseudomonas (58-70 mol\%; Palleroni, 1984).

To determine the phylogenetic position of the novel isolates, their 16S rRNA gene sequences were analysed. The five isolates all had the same nucleotide sequence $(100 \%$ similarity). Sequence database searches (GenBank and Ribosomal Database Project libraries) revealed that the novel isolates were phylogenetically most closely related to members of the genus Pseudomonas (results not shown). Phylogenetic trees obtained using the neighbour-joining (Fig. 1) and maximum-likelihood (data not shown) methods revealed a clear affiliation of the novel isolates (as exemplified by strain $\mathrm{OLi}^{\mathrm{T}}$ ) with the ' $P$. fluorescens group' of Anzai et al. (2000) and placed the novel strain on a separate branch within this intrageneric cluster containing P. fluorescens DSM $50090^{\mathrm{T}}$ (GenBank accession number Z76662). Strain $\mathrm{OLi}^{\mathrm{T}}$ displayed the closest sequence similarity with $P$. poae $(99 \cdot 8 \%$; AJ492829), $P$. trivialis (99.7\%; AJ492831) and P. extremorientalis (99.5\%; AJ492831). The other species most closely related (in terms of percentage sequence similarity) to strain $\mathrm{OLi}^{\mathrm{T}}$ were Pseudomonas constantinii (99.5\%; AF374472), Pseudomonas tolaasii (99.3\%; Z76670) and Pseudomonas palleroniana (99\%; AY091527). Although bootstrap resampling analysis shows that the association between strain $\mathrm{OLi}^{\mathrm{T}}$ and these species is not statistically significant, the branching position of this novel strain within this clade was relatively stable according to the two tree-making algorithms used in this study. The topology of the tree obtained by using the neighbour-joining method (Fig. 1) indicates that strain $\mathrm{OLi}^{\mathrm{T}}$ forms a separate branch together with $P$. poae and $P$. trivialis, but it was positioned with $P$. extremorientalis in the maximum-likelihood tree. Differences between strain $\mathrm{OLi}^{\mathrm{T}}$ and these species in

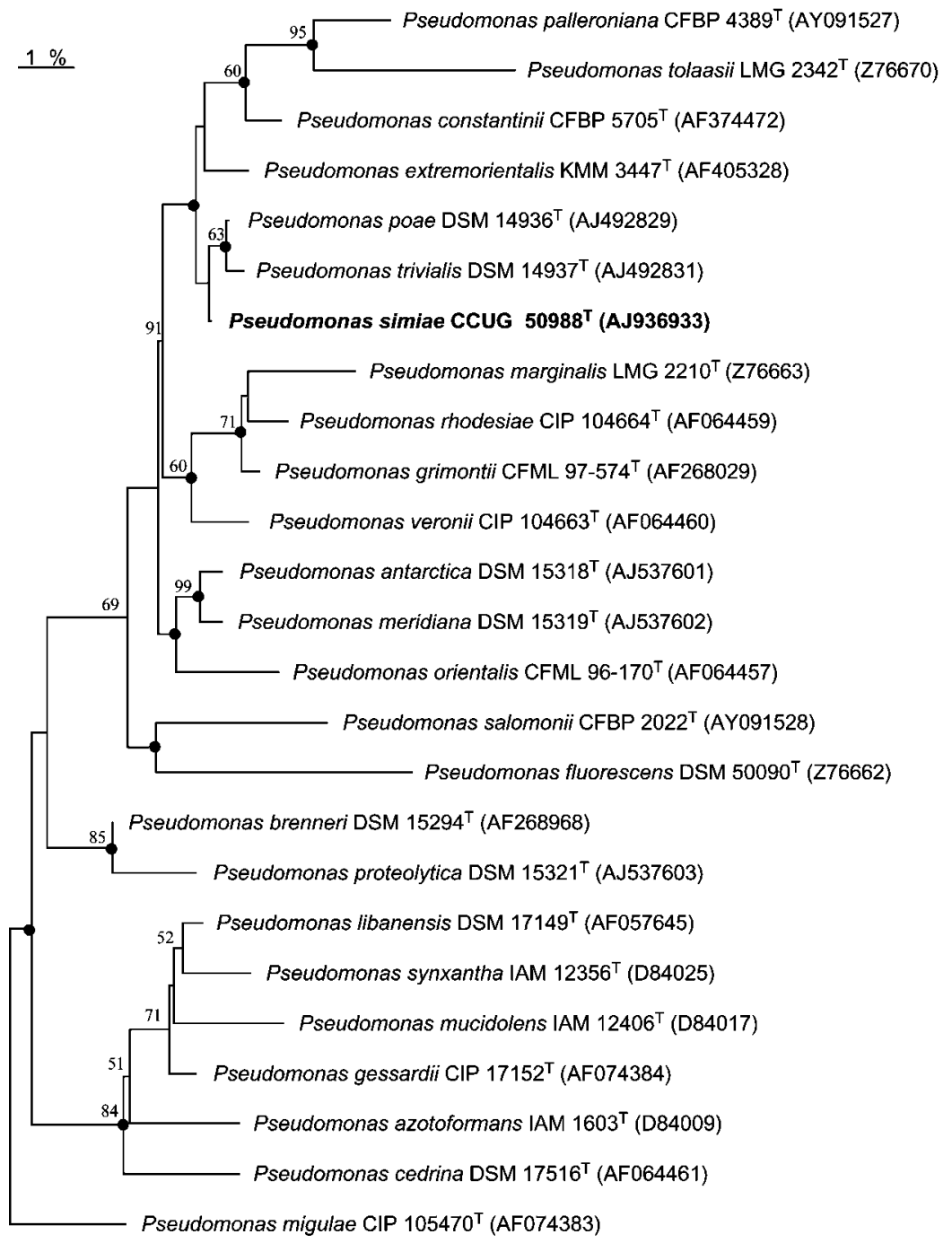

Fig. 1. Neighbour-joining unrooted tree, based on 16S rRNA gene sequence comparisons, showing the phylogenetic relationships of Pseudomonas simiae sp. nov. OLi' ${ }^{\top}$. Bootstrap values (expressed as percentages of 1000 replications) are given at the branching points. Solid circles indicate that the corresponding nodes (groupings) are also recovered in maximum-likelihood trees. Bar, $1 \%$ sequence divergence. 
terms of some of the biochemical characteristics and the phylogenetic position based on 16S rRNA gene sequence analysis suggested that the isolates obtained from the monkey clinical samples represent a novel species.

$16 \mathrm{~S}$ rRNA gene sequence divergence values greater than $3 \%$ are considered to represent a threshold for defining novel bacterial species (Stackebrandt \& Goebel, 1994). Nevertheless, some novel species described as belonging to the genus Pseudomonas have exhibited 16S rRNA gene sequences that were more than $99 \%$ similar to closely related validated species (Behrendt et al., 2003), indicating that, within the genus Pseudomonas, species delineation cannot be based exclusively on 16S rRNA gene sequence similarities. DNA-DNA hybridization experiments are considered the key method for determining the taxonomic position at species level, with DNA-DNA hybridization values of at least $70 \%$ being the threshold for species delineation (Wayne et al., 1987). For DNA-DNA hybridization studies, two of the novel clinical isolates $\left(\mathrm{OLi}^{\mathrm{T}}\right.$ and $\mathrm{MLi}$ ) and some closely related species of the genus Pseudomonas were selected on the basis of phenotypic and 16S rRNA gene sequence analyses. When the two clinical isolates were subjected to a chromosomal DNA-DNA hybridization study, they showed $99 \%$ DNA-DNA relatedness with each other, demonstrating that they are members of the same species. The DNA-DNA reassociation values between the clinical strain $\mathrm{OLi}^{\mathrm{T}}$ and $P$. poae DSM $14936^{\mathrm{T}}, P$. trivialis DSM $14937^{\mathrm{T}}$ and P. extremorientalis KMM $3447^{\mathrm{T}}$ were 23,2 and $30 \%$, respectively, indicating a separate species status for strain $\mathrm{OLi}^{\mathrm{T}}$ (Wayne et al., 1987). It is clear from the polyphasic taxonomic study that the five clinical isolates should be considered as representing a distinct species within the genus Pseudomonas, for which the name Pseudomonas simiae sp. nov. is proposed. Furthermore, the novel bacterium is also phenotypically very different from all recognized Pseudomonas species. In particular, the novel bacterium can be readily distinguished from other phylogenetically closely related species (Table 1).

All of the novel clinical isolates displayed undistinguishable macrorestriction patterns in PFGE analyses with both enzymes, indicating that they are probably clonal in origin. Only the isolate from the lung of the monkey offspring was recovered in pure culture; this, together with the histopathological findings, is strongly indicative of the clinical significance of Pseudomonas simiae sp. nov. as being responsible for the pneumonic infection observed in the animal. This association could not be established unambiguously with respect to the female monkey, making it difficult, therefore, to determine the potential pathogenic role of $P$. simiae in monkeys. The formal description of this novel species will facilitate its identification in veterinary clinical laboratories, thereby permitting the future evaluation of its distribution, clinical prevalence and possible association with disease. In this sense, $P$. simiae can be easily differentiated from other Pseudomonas species (e.g. P. aeruginosa or $P$. fluorescens) commonly isolated from
Table 1. Characteristics useful in differentiating Pseudomonas simiae sp. nov. from the closest phylogenetic relatives

Taxa: 1, Pseudomonas simiae sp. nov. (five strains); 2, P. poae; 3, P. trivialis; 4, P. extremorientalis; 5, P. constantinii; 6, Pseudomonas veronii; 7, Pseudomonas rhodesiae; 8, P. palleroniana; 9, P. tolaasii; 10, Pseudomonas marginalis; 11, Pseudomonas grimontii. Data for Pseudomonas species were obtained from Elomari et al. (1996), Dabboussi et al. (1999, 2002), Baïda et al. (2002), Ivanova et al. (2002), Munsch et al. (2002), Gardan et al. (2002) and Behrendt et al. (2003). P. poae and P. trivialis can be distinguished from $P$. simiae by their ability to assimilate glucuronamide, but not $\alpha$-cyclodextrin or dextrin and a negative reaction in tests for arginine dihydrolase. P. extremorientalis can be distinguished from $P$. simiae by the ability to assimilate glucuronamide, but not $\alpha$-cyclodextrin. + , Positive reaction; - , negative reaction, $v$, variable reaction; ND, not determined.

\begin{tabular}{|c|c|c|c|c|c|c|c|c|c|c|}
\hline Characteristic & 1 & 2 & 3 & 4 & 5 & 6 & 7 & 8 & 9 & 1011 \\
\hline Nitrate reduction & + & - & - & + & - & + & $-*$ & - & - & ++ \\
\hline Aesculin hydrolysis & - & + & + & ND & - & + & ND & - & - & $+\mathrm{ND}$ \\
\hline Gelatinase & + & $\mathrm{V}$ & $\mathrm{V}$ & - & + & $\mathrm{V}$ & - & + & + & $+\mathrm{ND}$ \\
\hline \multicolumn{11}{|l|}{ Assimilation of: } \\
\hline Sucrose & - & + & - & + & $\mathrm{V}$ & + & $-\dagger$ & + & $+\ddagger$ & ++ \\
\hline Maltose & - & - & - & + & - & + & - & ND & + & +- \\
\hline D-Trehalose & - & + & + & + & + & $\mathrm{V}$ & + & + & + & ++ \\
\hline$\alpha$-D-Glucose & + & $\mathrm{V}$ & + & - & + & + & + & + & + & ++ \\
\hline D-Galactose & + & + & + & + & + & + & + & ND & - & ++ \\
\hline Lactose & - & - & - & - & - & - & - & ND & + & +- \\
\hline Melibiose & - & - & - & - & - & - & - & - & + & +- \\
\hline L-Rhamnose & - & - & $\mathrm{V}$ & - & - & - & - & - & + & $\mathrm{V}+$ \\
\hline D-Mannitol & + & + & + & + & + & + & $-\dagger$ & ND & - & ++ \\
\hline L-Phenylalanine & - & - & - & - & ND & + & + & + & + & $+\mathrm{ND}$ \\
\hline$N$-Acetyl-D-glucosamine & - & - & $\mathrm{V}$ & + & + & + & + & $\mathrm{ND}$ & ND & ++ \\
\hline i-Erythritol & + & - & - & - & ND & + & - & + & + & $\mathrm{V}+$ \\
\hline D-Xylitol & - & - & - & + & + & - & - & - & + & $\mathrm{V}-$ \\
\hline Adonitol & + & - & - & - & + & - & - & - & - & -- \\
\hline myo-Inositol & + & + & + & - & + & + & + & $\mathrm{ND}$ & + & ++ \\
\hline Itaconic acid & - & + & + & + & + & + & - & + & + & ++ \\
\hline Putrescine & - & + & V & - & + & ND & ND & ND & ND & ++ \\
\hline L-Ornithine & + & $\mathrm{V}$ & $\mathrm{V}$ & - & ND & $\mathrm{V}$ & - & + & ND & $\mathrm{V} \mathrm{ND}$ \\
\hline
\end{tabular}

${ }^{\star}$ Positive reaction according to Dabboussi et al. (1999).

$\dagger$ Positive reaction according to Elomari et al. (1996).

$\ddagger$ Negative reaction according to Gardan et al. (2002).

animals with infections by applying several biochemical tests (Baïda et al., 2002; Catara et al., 2002; Ivanova et al., 2002).

\section{Description of Pseudomonas simiae sp. nov.}

Pseudomonas simiae (si'mi.ae. L. gen. n. simiae of an ape, of a monkey).

Gram-negative, catalase- and oxidase-positive, strictly aerobic and motile rods approximately $1-1.5 \mu \mathrm{m}$ in size. Cells produce a yellow pigment on tryptic soy agar. Colonies 
on Columbia blood agar are circular, non-pigmented and slightly haemolytic. Temperature range for growth is $4-37^{\circ} \mathrm{C}$; optimal growth occurs at $30^{\circ} \mathrm{C}$. Growth occurs in the presence of $6.5 \% \mathrm{NaCl}$. Fluorescent pigment is produced on King's medium B. The isolates reduce nitrate and hydrolyse gelatin. None of the isolates produces acid from glucose, acetoin or $\beta$-galactosidase. Reaction for arginine dihydrolase is positive. Urea and aesculin are not hydrolysed. The following carbon substrates are assimilated: $\alpha$-cyclodextrin, dextrin, glycogen, Tweens 40 and 80, adonitol, L-arabinose, D-arabitol, i-erythritol, D-fructose, D-galactose, $\alpha$-D-glucose, myo-inositol, D-mannitol, Dmannose, D-psicose, D-sorbitol, methyl pyruvate, monomethyl succinate, acetic acid, cis-aconitic acid, citric acid, formic acid, D-galactonic acid lactone, D-galacturonic acid, D-gluconic acid, D-glucosaminic acid, D-glucuronic acid, $\alpha$-hydroxybutyric acid, $\beta$-hydroxybutyric acid, $p$-hydroxyphenylacetic acid, $\alpha$-ketobutyric acid, $\alpha$-ketoglutaric acid, $\alpha$ ketovaleric acid, DL-lactic acid, malonic acid, propionic acid, quinic acid, D-saccharic acid, succinic acid, bromosuccinic acid, succinamic acid, L-alaninamide, D-alanine, Lalanine, L-alanyl glycine, L-asparagine, L-aspartic acid, L-glutamic acid, glycyl L-glutamic acid, L-histidine, hydroxy-L-proline, L-leucine, L-ornithine, L-proline, Lpyroglutamic acid, L-serine, L-threonine, DL-carnitine, $\gamma$ aminobutyric acid, urocanic acid, inosine, uridine, 2 -aminoethanol, glycerol and DL- $\alpha$-glycerol phosphate. None of the isolates assimilated $N$-acetyl-D-galactosamine, $N$-acetyl-D-glucosamine, D-cellobiose, L-fucose, gentiobiose, $\alpha$-D-lactose, lactulose, maltose, D-melibiose, methyl $\beta$-D-glucoside, D-raffinose, L-rhamnose, sucrose, D-trehalose, turanose, xylitol, $\gamma$-hydroxybutyric acid, itaconic acid, sebacic acid, glucuronamide, glycyl L-aspartic acid, Lphenylalanine, D-serine, thymidine, phenylethylamine, putrescine, 2,3-butanediol, glucose 1-phosphate or glucose 6-phosphate. Esterase (C4), ester lipase (C8), leucine arylamidase and acid phosphatase activities, and a weak reaction for valine arylamidase are detected. Alkaline phosphatase, lipase, cystine arylamidase, trypsin, chymotrypsin, phosphoamidase, $\alpha$-galactosidase, $\beta$-galactosidase, $\beta$-glucuronidase, $\alpha$-glucosidase, $\beta$-glucosidase, $N$-acetyl $\beta$ glucosamidase, $\alpha$-mannosidase and $\alpha$-fucosidase are not produced. The major fatty acids are $\mathrm{C}_{16: 0}, \mathrm{C}_{16: 1} \omega 7 c$, $\mathrm{C}_{18: 1} \omega 7 c$ and $\mathrm{C}_{17: 0}$ cyclo. The DNA G+C content of strain $\mathrm{OLi}^{\mathrm{T}}$ is $49 \cdot 7 \mathrm{~mol} \%\left(T_{\mathrm{m}}\right)$.

The type strain, $\mathrm{OLi}^{\mathrm{T}}\left(=\right.$ CCUG $\left.50988^{\mathrm{T}}=\mathrm{CECT} 7078^{\mathrm{T}}\right)$, was isolated from the liver of a monkey with acute bronchopneumonia and bacteraemia.

\section{Acknowledgements}

A. I. V. has a fellowship from the Ramon y Cajal Program (Spanish Ministry of Science and Technology/UCM). The authors thank E. P. Ivanova of the Pacific Institute of Bioorganic Chemistry of the FarEastern Branch of the Russian Academy of Sciences and U. Behrendt of the Centre for Agricultural Landscape and Land Use Research (ZALF) (Institute of Primary Production and Microbial Ecology of Germany) for providing reference strains.

\section{References}

Anzai, Y., Kim, H., Park, J. Y., Wakabayashi, H. \& Oyaizu, H. (2000). Phylogenetic affiliation of the pseudomonads based on 16S rRNA sequence. Int J Syst Evol Microbiol 50, 1563-1589.

Arahal, D. R., Garcia, M. T., Vargas, C., Canovas, D., Nieto, J. J. \& Ventosa, A. (2001). Chromohalobacter salexigens sp. nov., a moderately halophilic species that includes Halomonas elongata DSM 3043 and ATCC 33174. Int J Syst Evol Microbiol 51, 1457-1462.

Baïda, N., Yazourh, A., Singer, E. \& Izard, D. (2002). Pseudomonas grimontii sp. nov. Int J Syst Evol Microbiol 52, 1497-1503.

Behrendt, U., Ulrich, A. \& Schumann, P. (2003). Fluorescent pseudomonads associated with the phyllosphere of grasses; Pseudomonas trivialis sp. nov., Pseudomonas poae sp. nov. and Pseudomonas congelans sp. nov. Int J Syst Evol Microbiol 53, 1461-1469.

Blanco, M. M., Gibello, A., Vela, A. I., Moreno, M. A., Domínguez, L. \& Fernández-Garayzábal, J. F. (2002). PCR detection and PFGE DNA macrorestriction analyses of clinical isolates of Pseudomonas anguilliseptica from winter disease outbreaks in sea bream Sparus aurata. Dis Aquat Organ 50, 19-27.

Catara, V., Sutra, L., Morineau, A., Achouak, W., Christen, R. \& Gardan, L. (2002). Phenotypic and genomic evidence for the revision of Pseudomonas corrugata and proposal of Pseudomonas mediterranea sp. nov. Int J Syst Evol Microbiol 52, 1749-1758.

Coalson, J. J., Olsberg, C. A., Johanson, W. G., Jr \& deLemos, R. A. (1988). The role of infection in the premature baboon with lung injury. Prog Clin Biol Res 264, 213-221.

Collins, M. D., Falsen, E., Foster, G., Monastério, R., Dominguez, L. \& Fernández-Garayzábal, J. F. (1999). Helcococcus ovis sp. nov., a Gram-positive organism from sheep. Int J Syst Bacteriol 49, 14291432.

Dabboussi, F., Hamze, M., Elomari, M., Verhille, S., Baida, N., Izard, D. \& Leclerc, H. (1999). Pseudomonas libanensis sp. nov., a new species isolated from Lebanese spring waters. Int J Syst Bacteriol 49, 1091-1101.

Dabboussi, F., Hamze, M., Singer, E., Geoffroy, V., Meyer, J. M. \& Izard, D. (2002). Pseudomonas mosselii sp. nov., a novel species isolated from clinical specimens. Int J Syst Evol Microbiol 52, 363-376.

Daly, M., Power, E., Bjorkroth, J., Sheehan, P., O'Connell, A., Colgan, M., Korkeala, H. \& Fanning, S. (1999). Molecular analysis of Pseudomonas aeruginosa: epidemiological investigation of mastitis outbreaks in Irish dairy herds. Appl Environ Microbiol 65, 2723-2729.

De Ley, J. \& Tijtgat, R. (1970). Evaluation of membrane filter methods for DNA-DNA hybridization. Antonie van Leeuwenhoek 36, 461-474.

Elomari, M., Coroler, L., Hoste, B., Gillis, M., Izard, D. \& Leclerc, H. (1996). DNA relatedness among Pseudomonas strains isolated from natural mineral waters and proposal of Pseudomonas veronii sp. nov. Int J Syst Bacteriol 46, 1138-1144.

Felsenstein, J. (1993). PHYLIP (phylogeny inference package), version 3.5c. Distributed by the author. Department of Genome Sciences, University of Washington, Seattle, USA.

Ferragut, C. \& Leclerc, H. (1976). Étude comparative des méthodes de détermination du Tm de l'ADN bactérien. Ann Microbiol 127, 223-235.

Franzetti, F., Cernuschi, M., Esposito, R. \& Moroni, M. (1992). Pseudomonas infections in patients with AIDS and AIDS-related complex. J Intern Med 231, 437-443.

Gardan, L., Bella, P., Meyer, J. M., Christen, R., Rott, P., Achouak, W. \& Samson, R. (2002). Pseudomonas salomonii sp. nov., pathogenic on garlic, and Pseudomonas palleroniana sp. nov., isolated from rice. Int J Syst Evol Microbiol 52, 2065-2074.

Ivanova, E. P., Gorshkova, N. M., Sawabe, T. \& 8 other authors (2002). Pseudomonas extremorientalis sp. nov., isolated from a drinking water reservoir. Int J Syst Evol Microbiol 52, 2113-2120. 
Jiraskova, N. \& Rozsival, P. (1998). Delayed-onset Pseudomonas stutzeri endophthalmitis after uncomplicated cataract surgery. $J$ Cataract Refract Surg 24, 866-867.

Johnson, J. L. (1994). Similarity analysis of DNAs. In Methods for General and Molecular Bacteriology, pp. 655-681. Edited by P. Gerhardt, R. G. E. Murray, W. A. Wood \& N. R. Krieg. Washington, DC: American Society for Microbiology.

Kämpfer, P. \& Kroppenstedt, R. M. (1996). Numerical analysis of fatty acid patterns of coryneform bacteria and related taxa. Can $J$ Microbiol 42, 989-1005.

King, E. O., Ward, M. K. \& Raney, D. E. (1954). Two simple media for the demonstration of pyocyanin and fluorescin. J Lab Clin Med 44, 301-307.

Las Heras, A., Domínguez, L., Lopez, I. \& Fernández-Garayzábal, J. F. (1999). Outbreak of acute ovine mastitis associated with Pseudomonas aeruginosa infection. Vet Rec 145, 111-112.

Lausen, N. C., Richter, A. G. \& Lage, A. L. (1986). Pseudomonas aeruginosa infection in squirrel monkeys. J Am Vet Med Assoc 189, 1216-1218.

Lombardi, G., Luzzaro, F., Docquier, J. D., Riccio, M. L., Perilli, M., Coli, A., Amicosante, G., Rossolini, G. M. \& Toniolo, A. (2002). Nosocomial infections caused by multidrug-resistant isolates of Pseudomonas putida producing VIM-1 metallo- $\beta$-lactamase. J Clin Microbiol 40, 4051-4055.

Marmur, J. (1961). A procedure for the isolation of deoxyribonucleic acid from microorganisms. J Mol Biol 3, 208-219.

Marmur, J. \& Doty, P. (1962). Determination of the base composition of deoxyribonucleic acid from its thermal denaturation temperature. $J$ Mol Biol 5, 109-118.

Munsch, P., Alatossava, T., Marttinen, N., Meyer, J. M., Christen, R. \& Gardan, L. (2002). Pseudomonas costantinii sp. nov., another causal agent of brown blotch disease, isolated from cultivated mushroom sporophores in Finland. Int J Syst Evol Microbiol 52, 1973-1983.

Owen, R. J. \& Hill, L. R. (1979). The estimation of base compositions, base pairing and genome size of bacterial deoxyribonucleic acids. In Identification Methods for Microbiologists, 2nd edn, pp. 217-296. Edited by F. A. Skinner \& D. W. Lovelock. London: Academic Press.

Owen, R. J. \& Pitcher, D. (1985). Current methods for estimating DNA base composition and levels of DNA-DNA hybridization. In
Chemical Methods in Bacterial Systematics, pp. 67-93. Edited by M. Goodfellow \& E. Minnikin. London: Academic Press.

Oyaizu, H. \& Komagata, K. (1983). Grouping of Pseudomonas species on the basis of cellular fatty acid composition and the quinone system with special reference to the existence of 3-hydroxy fatty acids. J Gen Appl Microbiol 29, 17-40.

Page, R. D. M. (1996). TREEVIEW: an application to display phylogenetic trees on personal computers. Comput Appl Biosci 12, 357-358.

Palleroni, N. J. (1984). Genus Pseudomonas Migula 1894, $237^{\mathrm{AL}}$. In Bergey's Manual of Systematic Bacteriology, vol. 1, pp. 141-199. Edited by N. R. Krieg \& J. G. Holt. Baltimore: Williams \& Wilkins.

Palleroni, N. J. (1993). Pseudomonas classification. A new case history in the taxonomy of gram-negative bacteria. Antonie van Leeuwenhoek 64, 231-251.

Pearson, W. R. (1994). Using the FASTA program to search protein and DNA sequence databases. Methods Mol Biol 24, 307-331.

Poirel, L., Lebessi, E., Castro, M., Fevre, C., Foustoukou, M. \& Nordmann, P. (2004). Nosocomial outbreak of extended-spectrum beta-lactamase SHV-5-producing isolates of Pseudomonas aeruginosa in Athens, Greece. Antimicrob Agents Chemother 48, 2277-2279.

Puzenat, E., Chirouze, C., Khayat, N., Aubin, F., Estavoyer, J. M., Humbert, P. \& Hoen, B. (2004). Ecthyma gangrenosum caused by Pseudomonas stutzeri with bacteraemia and systemic vascularitis. Rev Med Interne 25, 315-358.

Rasmussen, S. W. (1995). DNATools, a software package for DNA sequence analysis. Copenhagen: Carlsberg Laboratory.

Saitou, N. \& Nei, M. (1987). The neighbor-joining method: a new method for reconstructing phylogenetic trees. Mol Biol Evol 4, 406-425.

Smith, J., Ashhurst-Smith, C. \& Norton, R. (2002). Pseudomonas fluorescens pseudobacteraemia: a cautionary lesson. J Paediatr Child Health 38, 63-65.

Stackebrandt, E. \& Goebel, B. M. (1994). Taxonomic note: a place for DNA-DNA reassociation and 16S rRNA sequence analysis in the present species definition in bacteriology. Int J Syst Bacteriol 44, 846-849.

Wayne, L. G., Brenner, D. J., Colwell, R. R. \& 9 other authors (1987). International Committee on Bacterial Systematics. Report of the ad hoc committee on reconciliation of approaches to bacterial systematics. Int J Syst Bacteriol 37, 463-464. 